\title{
DESAIN FILTER 1D LOWPASS INTERPOLATED FINITE IMPULSE RESPONSE (IFIR) UNTUK SPECTRAL DECOMPOSITION PADA PEMODELAN 3D DATA GRAVITASI BAWAH PERMUKAAN
}

\author{
Hanif Fajrul Falah, Firman Syaifuddin, dan Widya Utama \\ Departemen Teknik Geofisika, Fakultas Teknik Sipil, Lingkungan, dan Kebumian, Institut Teknologi Sepuluh Nopember, \\ Surabaya \\ e-mail:widya@geofisika.its.ac.id
}

\begin{abstract}
Abstrak. Operator lowpass filter Interpolated Finite Impulse Response (IFIR) yang memiliki karakteristik cutoff frequency sempit digunakan untuk pemisahan spektrum pada Spectral Decomposition. Penelitian ini bertujuan melakukan desain filter 1D untuk Spectral Decomposition pada pemodelan 3D struktur bawah permukaan dari data gravitasi. Kandungan bilangan gelombang profil anomali dipisahkan dari profil digitasi peta kontur Anomali Gravitasi Bouguer menggunakan Algoritma Fast Fourier Transform (FFT). Nilai bilangan gelombang dipakai sebagai nilai cutoff frequency untuk mendesain filter pada satu iterasi. Kemudian dilakukan konvolusi filter IFIR 1D terhadap profil gravitasi, sehingga didapatkan spektrum pada kedalaman tertentu yang ditentukan dari nilai bilangan gelombangnya. Spektrum divalidasi dengan lokasi hiposenter gempa sebagai indikator struktur bawah permukaan, kemudian diinterpolasi secara geostatistik untuk membuat model peta kontur 2D geometri bawah permukaan, dan dilakukan gridding untuk mendapat model 3D. Pemodelan Anomali Bouguer menggunakan filter ini mampu memberikan petunjuk struktur geologi pada kedalaman tertentu berdasarkan bentuk spektrum. Pengaruh filter IFIR adalah mengatenuasi bilangan gelombang tinggi, memberikan karakteristik regional pada model kedalaman dangkal akibat konten bilangan gelombang yang lebih sedikit.
\end{abstract}

Kata Kunci: spectral decomposition; interpolated finite impulse response; anomali bouguer

\begin{abstract}
Interpolated Finite Impulse Response (IFIR) lowpass filter operator with narrow cutoff frequency characteristic is used to decompose Bouguer Gravity Anomaly Spectra. The purpose of this research is to design a suitable 1D filter for Spectral Decomposition on Bouguer Gravity Anomaly data to create subsurface structure 3D model. One-dimension profiles digitized from Surface Bouguer Gravity Anomaly are decomposed into different wavenumber values using Fast Fourier Transform (FFT). The obtained wavenumber values are used as cutoff frequency value for filter designing at given iteration. Filtering is done by convolution of 1D IFIR filter Surface Bouguer Gravity Anomaly. The results are spectra at a depth given by its corresponding wavenumber. Spectra are validated using earthquake hypocenter locations as an indicator for subsurface structure. One-dimension spectra are then interpolated using geostatistical modelling to create 2D subsurface contour map, and then gridded to achieve 3D model. Modelling for Bouguer anomaly using one-dimension IFIR lowpass filter can give some geological structure insight between spectra at given depth. IFIR Filter attenuates high frequency components, giving more regional characteristic at lower depth models due to less adequate amount of wavenumber passed.

Keywords: spectral decomposition; interpolated finite impulse response; bouguer anomaly
\end{abstract}

\section{PENDAHULUAN}

Pemodelan data gravitasi memiliki ambiguitas dan subjektivitas yang tinggi meskipun telah dikontrol oleh data pendukung. Suatu anomali gravitasi dapat menghasilkan lebih dari 10.000 variasi model (Biswas, 2015). Anomali gravitasi merupakan superposisi dari banyak spektrum dari dangkal hingga dalam dengan densitas dan geometri berbeda. Apabila dapat dilakukan pemisahan spektrum gravitasi pada tiap kedalaman penyebab superposisi anomali, data objektif pada tiap kedalaman dapat diperoleh. Dengan demikian, ambiguitas pemodelan dapat dikurangi. Dekomposisi sinyal anomali berdasarkan komponen frekuensi dapat dilakukan untuk memisahkan anomali dangkal dengan bilangan gelombang tinggi, dari anomali dalam yang memiliki bilangan gelombang rendah. Kemudian baru dapat dilanjutkan ke tahap pemodelan hingga interpretasi (Handyarso dan Kadir, 2017). Pemodelan menggunakan dekomposisi sinyal anomali 
berdasarkan frekuensi kedalaman dapat menunjang hal tersebut (Setiawan dan Setiawan, 2017).

Pada penelitian yang telah dilakukan sebelumnya (Pradana, 2017) dilakukan aplikasi metode Spectral Decomposition dalam studi kasus pemodelan bentuk subduksi di bagian Timur Pulau Jawa melalui data gravitasi satelit. Dengan operator filter 1D lowpass, komponen frekuensi anomali gravitasi free air dapat dipisah menjadi anomali pada setiap kedalaman. Hasilnya, didapat bentuk model subduksi dengan kedalaman dangkal yang sesuai dengan geologi daerah penelitian. Model hasil divalidasi dengan data kontrol berupa persebaran hiposenter gempa dan model subduksi teoritis. Namun, filter 1D yang telah dibuat masih memiliki kekurangan berupa fasa luaran filter yang tidak linear. Penelitian ini dilakukan untuk melengkapi situs United States Geological Survey (USGS), dan Parameter Filter yang diambil dari penelitian sebelumnya oleh Pradana (2017), dengan penentuan kedalaman anomali hasil Spectral Decomposition adalah sebesar.

$$
d=\frac{1}{10 \times k}
$$

dengan:

$d$ : Kedalaman (meter)

$\lambda$ : Panjang Gelombang (meter)

$k$ : Komponen Frekuensi/Bilangan Gelombang ( $\pi \mathrm{rad} / \mathrm{sampel}$ )

Filter pada penelitian ini menggunakan 1D lowpass metode Interpolated Finite Impulse Response. Dilakukan Transformasi Fourier pada data input berupa profil sayatan 1D dari Anomali Bouguer. Transformasi Fourier didefinisikan dengan persamaan:

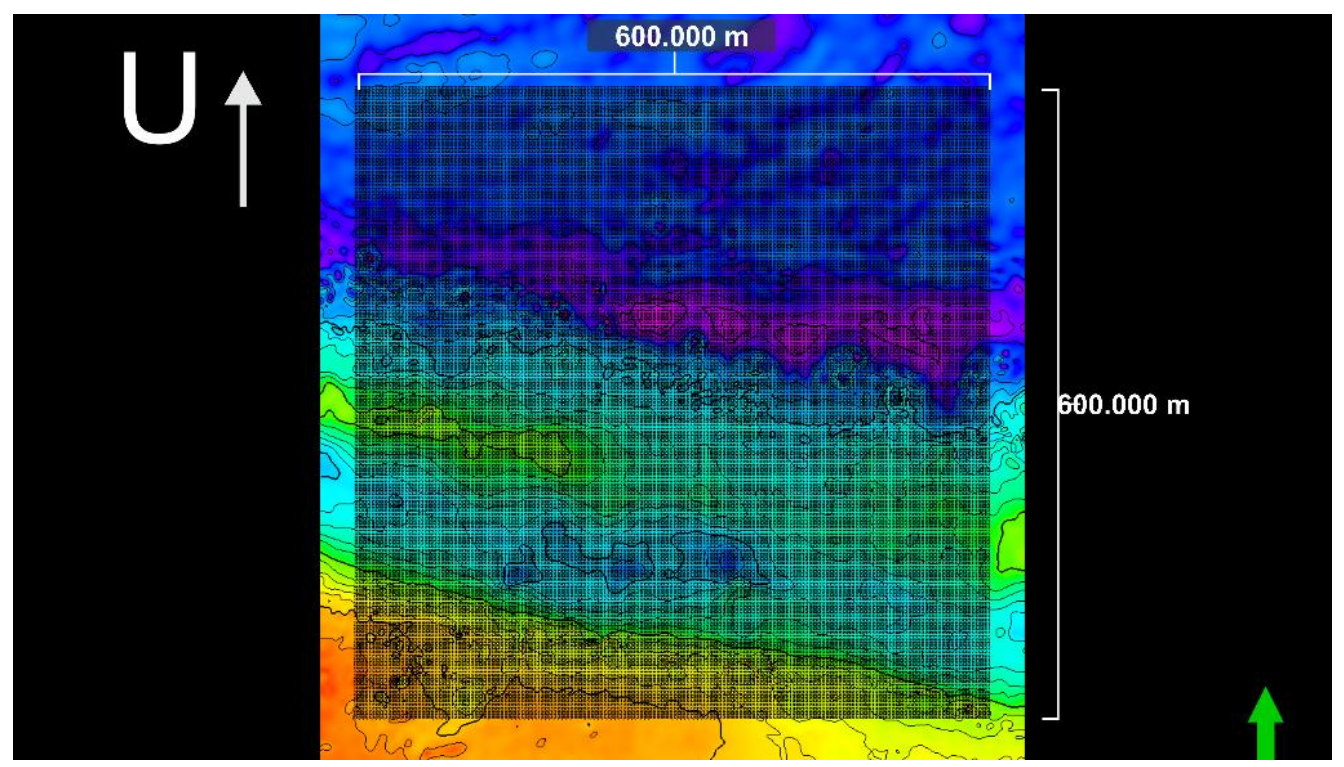

Gambar 1. Lintasan Digitasi untuk Pengambilan Profil Anomali Bouguer

penelitian sebelumnya. Mendesain filter 1D lowpass yang sesuai untuk metode Spectral Decomposition pada data gravitasi bawah permukaan, guna mendapatkan model 3D struktur bawah permukaan yang objektif.

\section{METODOLOGI}

Data yang digunakan dalam penelitian ini adalah Data Anomali Gravitasi Bouguer WGM2012 hasil pengukuran menggunakan citra satelit altimetri, Data Lokasi Hiposenter Gempa Bumi didapatkan dari

$$
G\left(k_{x}, k_{y}\right)=\int_{-\infty}^{\infty} \int_{-\infty}^{\infty} g(x, y) e^{-i\left(k_{x} x, k_{y} y\right)} d x d y
$$
dengan:

$G$ : Sinyal Gravitasi Domain Spasial (mGal) $g$ : Sinyal Gravitasi Domain Frekuensi (mGal) $k$ : Komponen Frekuensi/Bilangan Gelombang ( $\pi \mathrm{rad} / \mathrm{meter}$ ) 

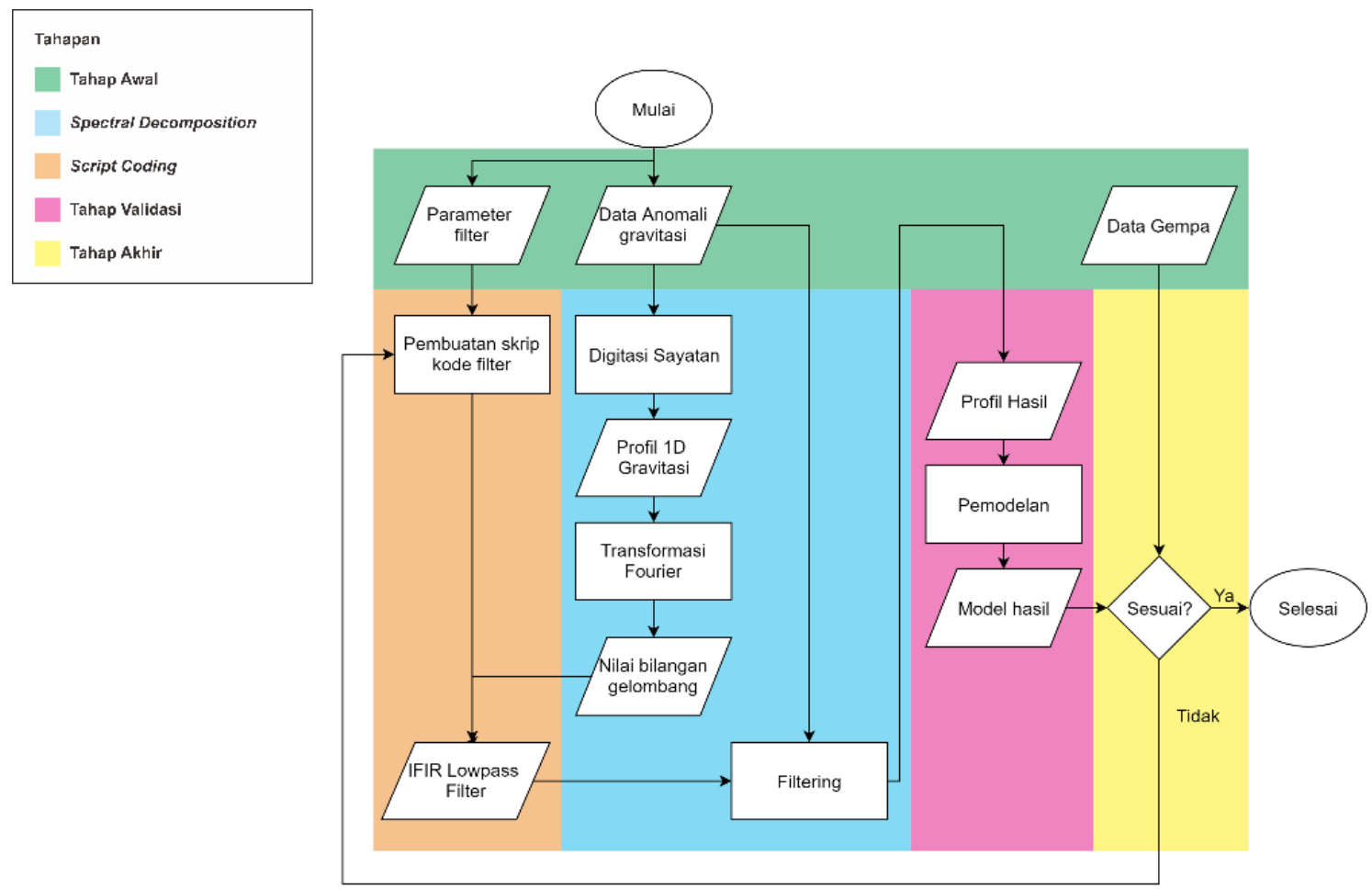

Gambar 2. Diagram Alur Penelitian

Sehingga didapatkan profil 1D dalam domain bilangan gelombang. Langkah berikutnya adalah melakukan pencacahan dan pemilihan bilangan gelombang berdasarkan jarak antar sampel. Nilai bilangan gelombang yang didapatkan kemudian digunakan sebagai nilai cutoff pada operator filter yang akan dibuat pada tiap iterasi. Dilakukan filtering pada profil awal menggunakan sebuah operator filter dengan nilai cutoff frequency ( $f c$ ) yang disesuaikan pada tiap iterasi. Tujuannya adalah untuk menghilangkan komponen frekuensi di atas nilai cutoff frequency $(f c)$ tersebut.

Hasil dari pengolahan data menggunakan filter yang telah dilakukan normalisasi dan disusun berdasarkan kedalaman kemudian dilakukan interpolasi metode pemodelan geostatistik. Model kemudian dianalisis secara kualitatif terhadap data titik hiposenter gempa untuk mendapatkan kesimpulan hasil dari penggunaan filtering dalam penentuan struktur bawah permukaan. Operator filter dikatakan sudah sesuai apabila hasil filtering memberikan model yang menunjukkan kemenerusan struktur subduksi yang berhimpit dengan titik-titik hiposenter gempa.

\section{HASIL DAN PEMBAHASAN}

Didapatkan hasil Spectral Decomposition respon dengan komponen frekuensi rendah memiliki magnitudo yang relatif lebih tinggi daripada komponen frekuensi tinggi menggunakan Fast Fourier Transform. Anomali gravitasi pada

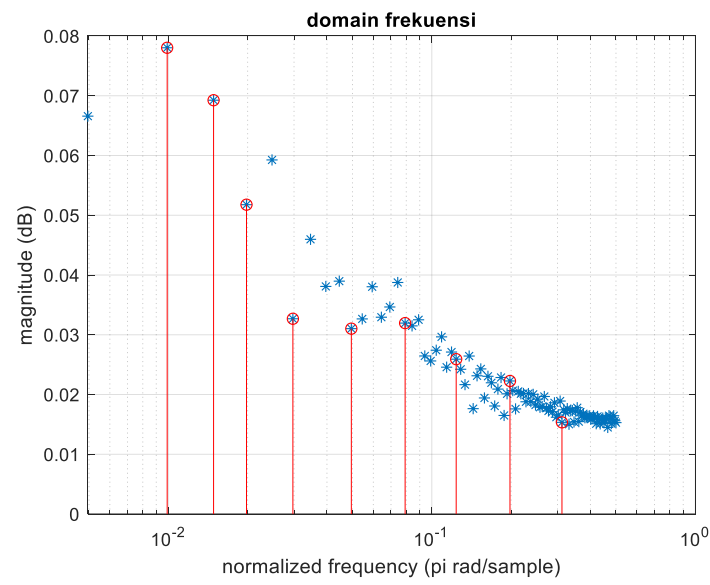

Gambar 3. Nilai Bilangan Gelombang sebagai Cutoff

Frequency untuk Operator Filter

kedalaman tertentu diindikasikan dengan nilai komponen frekuensi ini. Anomali gravitasi yang telah dilakukan Spectral Decomposition ini selanjutnya disebut sebagai spektrum. Langkah berikutnya 
adalah melakukan pencacahan dan pemilihan bilangan gelombang berdasarkan panjang lintasan sampel. Nilai bilangan gelombang yang didapat kemudian digunakan sebagai cutoff pada operator filter yang akan dibuat pada tiap iterasi. Pengambilan sampel poin dilakukan secara logaritmik. Tujuannya adalah untuk menyeimbangkan dominansi komponen frekuensi rendah, dengan komponen frekuensi tinggi yang memiliki magnitudo relatif rendah, namun lebih sering muncul dalam respon FFT. Apabila dilakukan pengambilan sampel secara linier, data pada komponen frekuensi tinggi dengan jarak antar kedalaman yang tidak terlalu signifikan akan lebih banyak diambil. Sehingga pada penyusunan spektrum di kedalaman, diambil sedikit saja spektrum frekuensi tinggi untuk efisiensi komputasi. Hal ini dilakukan dengan pengambilan sampel secara logaritmik.

Pada Gambar 3, titik sampel dengan warna merah menyatakan poin yang diambil sebagai cutoff frequency untuk filter. Informasi komponen frekuensi tersebut kemudian dijadikan nilai cutoff frequency operator filter tiap iterasi. Sebagai contoh, pada operator filter dengan cutoff frequency $=$ $4.49 \times 10^{-5}$., respon magnitudo Filter IFIR mempunyai respon magnitudo passband yang relatif konsisten pada $0 \mathrm{~dB}=1$, dan stopband yang menunjukkan pola perulangan akibat interpolasi pada metode desain IFIR. Meskipun demikian, nilai stopband berkisar pada $-30 \mathrm{~dB}$. Hal tersebut telah sesuai dengan spesifikasi penelitian sebelumnya. Sehingga, filter yang dikatakan telah memenuhi

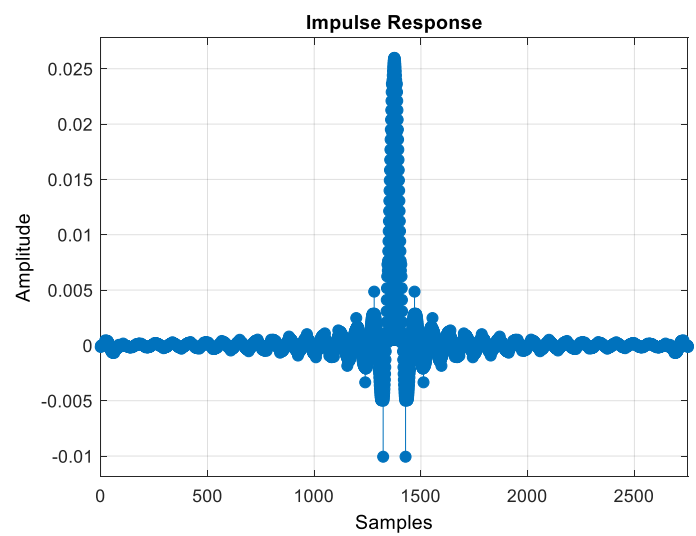

Gambar 4. Fungsi Respon Impuls IFIR pada Cutoff Frequency $=4.49 \times 10^{-5}$.

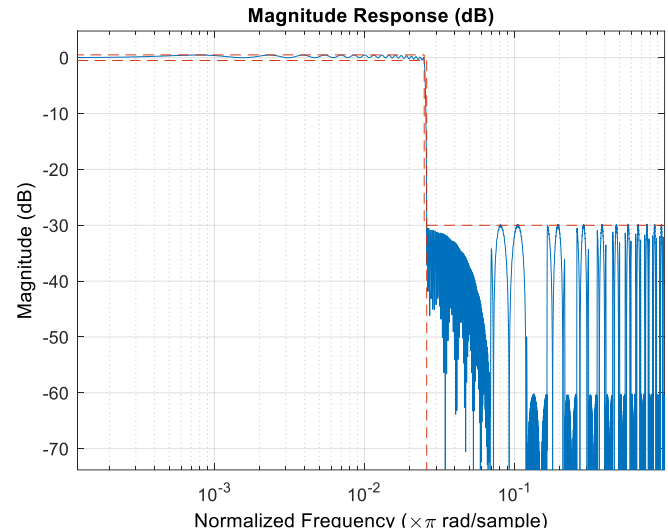

Gambar 5. Fungsi Respon Magnitudo IFIR pada Cutoff Frequency $=4.49 \times 10^{-5}$.

kriteria yang diperlukan. Pada Tabel 1 ditunjukkan nilai ordo dan delay pada masing - masing filter dengan cutoff frequency tertentu di setiap iterasi.

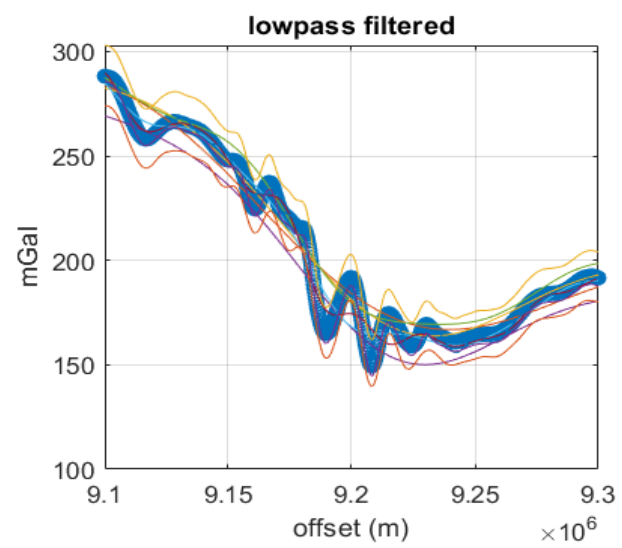

Gambar 6. Spektrum Vertikal filtered Menggunakan Filter IFIR

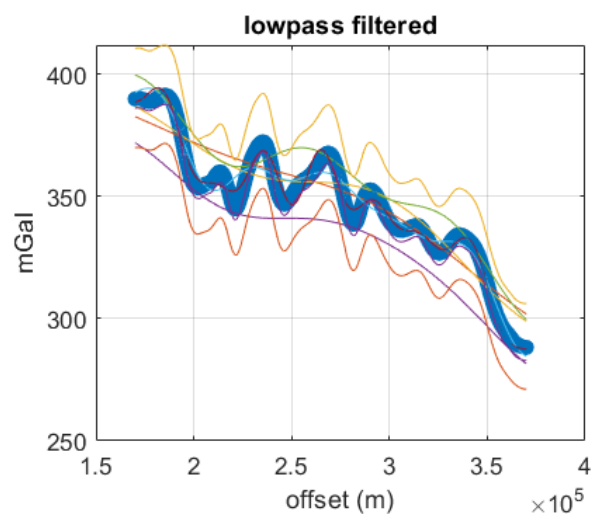

Gambar 7. Spektrum Horizontal filtered Menggunakan Filter IFIR

Ordo filter berkisar di sekitar nilai $2700-2800$. 
Dengan nilai ordo paling tinggi berada pada operator filter dengan cutoff frequency yang rendah. Hal ini disebabkan oleh struktur IFIR dibuat sehingga mempunyai transition band yang sempit, sehingga ordo dari filter berukuran sangat besar sebagai implikasi dari hal tersebut. Sedangkan nilai delay dari filter berada cenderung konsisten di sekitar nilai 1350 - 1400.

Tabel 1. Parameter Filter Ordo dan Delay pada MasingMasing Cutoff Frequency

\begin{tabular}{|c|c|c|c|}
\hline No & $\begin{array}{c}\text { Cutoff Frequency ( } \boldsymbol{\pi} \text { rad } \\
\text { /sampel) }\end{array}$ & $\begin{array}{c}\text { Ordo } \\
\text { (sampel) }\end{array}$ & $\begin{array}{c}\text { Group Delay } \\
\text { (sampel) }\end{array}$ \\
\hline 1 & $4.99 \times \mathbf{1 0}^{-\mathbf{6}}$ & 2785 & 1392.5 \\
\hline 2 & $9.99 \times \mathbf{1 0}^{-\mathbf{6}}$ & 2859 & 1429.5 \\
\hline 3 & $1.49 \times \mathbf{1 0}^{-\mathbf{5}}$ & 2837 & 1418.5 \\
\hline 4 & $1.99 \times \mathbf{1 0}^{-5}$ & 2800 & 1400 \\
\hline 5 & $2.99 \times \mathbf{1 0}^{-5}$ & 2763 & 1381.5 \\
\hline 6 & $4.99 \times \mathbf{1 0}^{-5}$ & 2766 & 1383 \\
\hline 7 & $7.99 \times \mathbf{1 0}^{-5}$ & 2751 & 1375.5 \\
\hline 8 & 0.000124 & 2757 & 1378.5 \\
\hline 9 & 0.000199 & 2762 & 1381 \\
\hline 10 & 0.000314 & 2712 & 1356 \\
\hline
\end{tabular}

Hasil dari filtering merupakan spektrum anomali gravitasi yang komponen frekuensinya telah diatenuasi untuk nilai di atas cutoff frequency pada iterasi tersebut. Hasilnya adalah spektrum anomali gravitasi yang secara teori merupakan respon anomali yang berasal dari kedalaman $d=1 /(10) \lambda$. Setelah input data spektrum diolah dalam program untuk dilakukan filtering melalui Spectral Decomposition, luaran yang didapat adalah profil 1D pada setiap kedalaman yang disusun berurutan

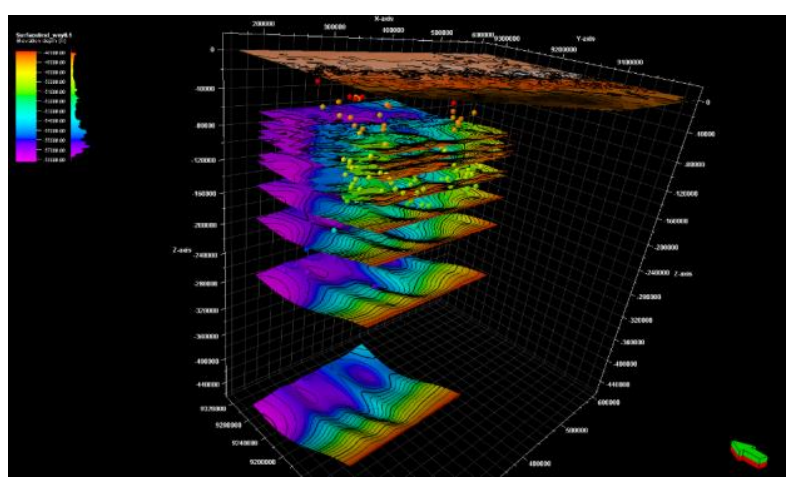

Gambar 8. Peta Kontur Hasil Interpolasi Sayatan Vertikal Tampak dari Arah Barat Daya

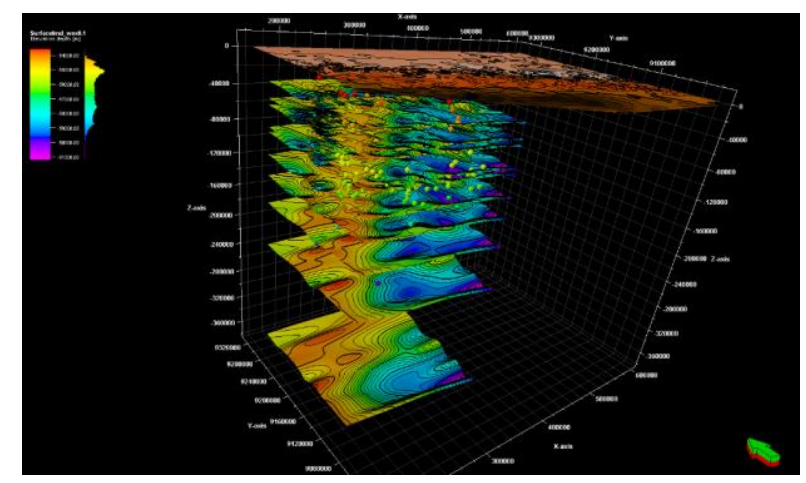

Gambar 9. Peta Kontur Hasil Interpolasi Sayatan Horizontal Tampak dari Arah Barat Daya

secara spasial untuk vertikal dan horizontal dalam format ASCII. Profil ini kemudian dilakukan pemodelan. Pada Gambar 5 ditunjukkan profil awal

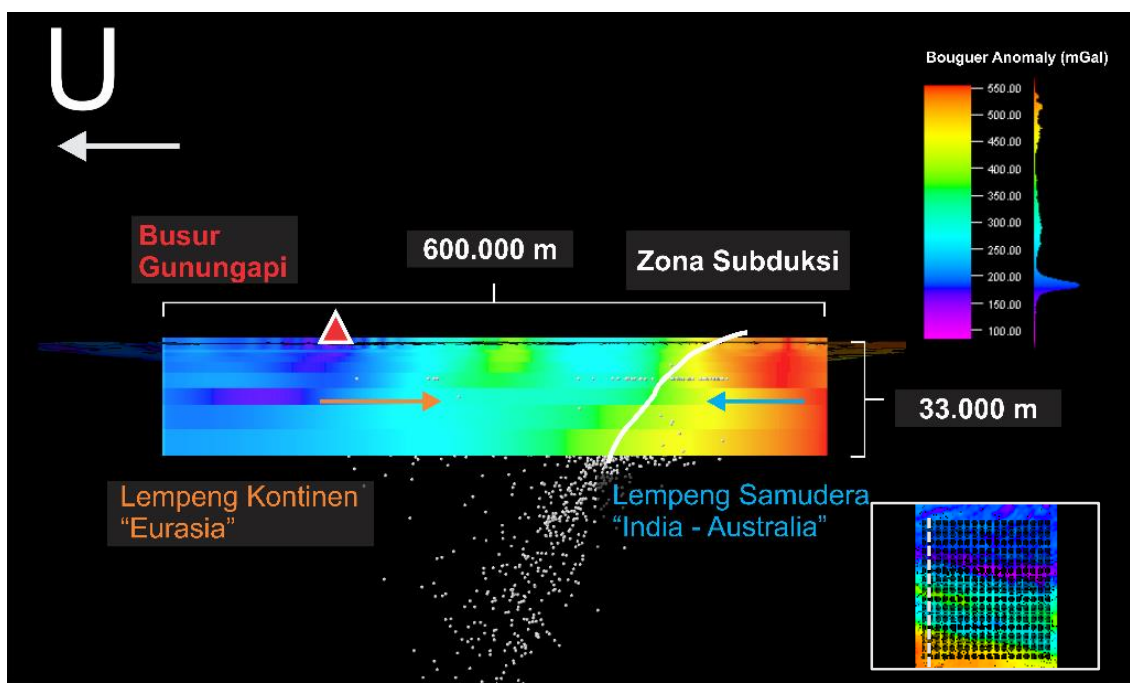

Gambar 10. Penampang Membujur Model 3D Anomali Gravitasi Bawah Permukaan, Tampak dari Barat, Offset $0 \mathrm{~km}$ 
dengan warna kurvan biru tua tebal dan spektrum hasil filtering dari sayatan vertikal, dan pada Gambar 6 adalah sayatan horizontal. Terlihat dari keduanya, bahwa pola yang diberikan pada spektrum hasil filtering dengan fc lebih rendah memberikan pola yang relatif halus daripada profil dengan fc lebih tinggi. Hal ini disebabkan oleh lebih sedikitnya data gravitasi pada cakupan area yang lebih luas. Pada Gambar 1, ditunjukkan pemodelan ini diambil dengan akuisisi data membujur dan melintang sepanjang $600 \mathrm{~km}$ dengan rasio 1:1. Jarak antar sampel pada satu sayatan adalah $2 \mathrm{~km}$, dengan jarak sayatan yang diambil adalah $2 \mathrm{~km}$.

Anomali gravitasi rendah merupakan respon

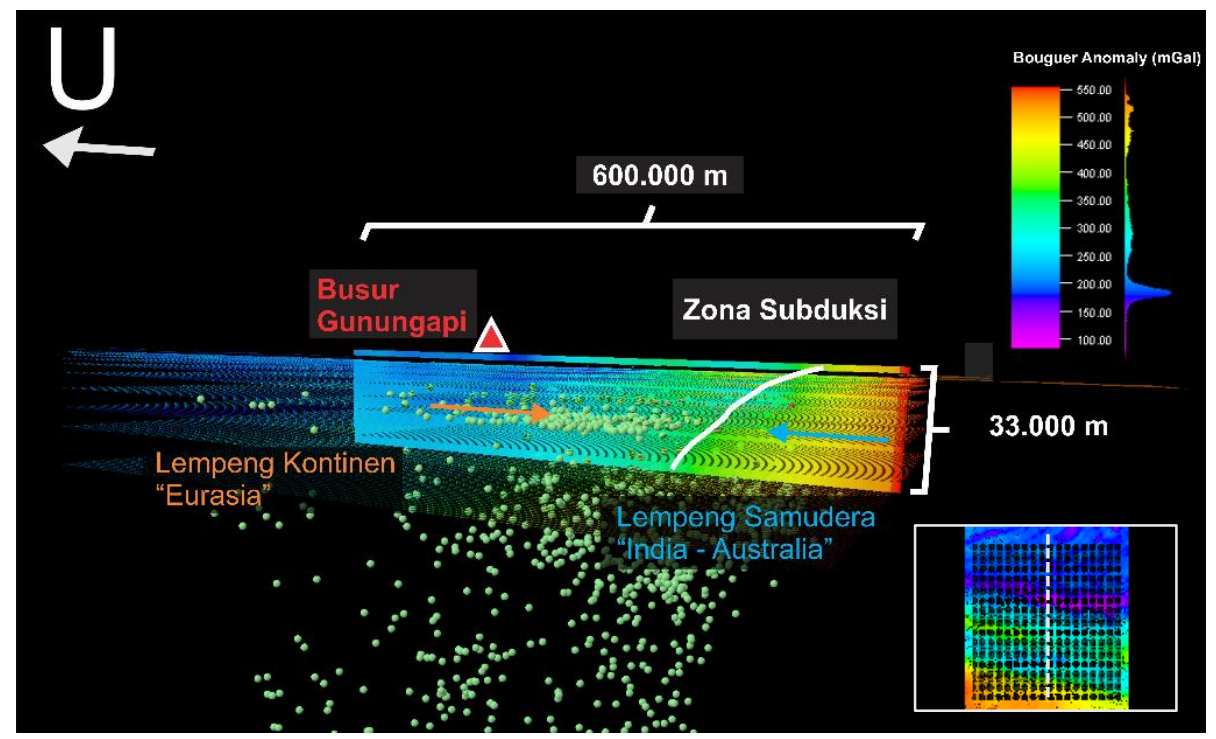

Gambar 11. Penampang Membujur Model 3D Anomali Gravitasi Bawah Permukaan, Tampak dari Barat Daya, Offset $360 \mathrm{~km}$

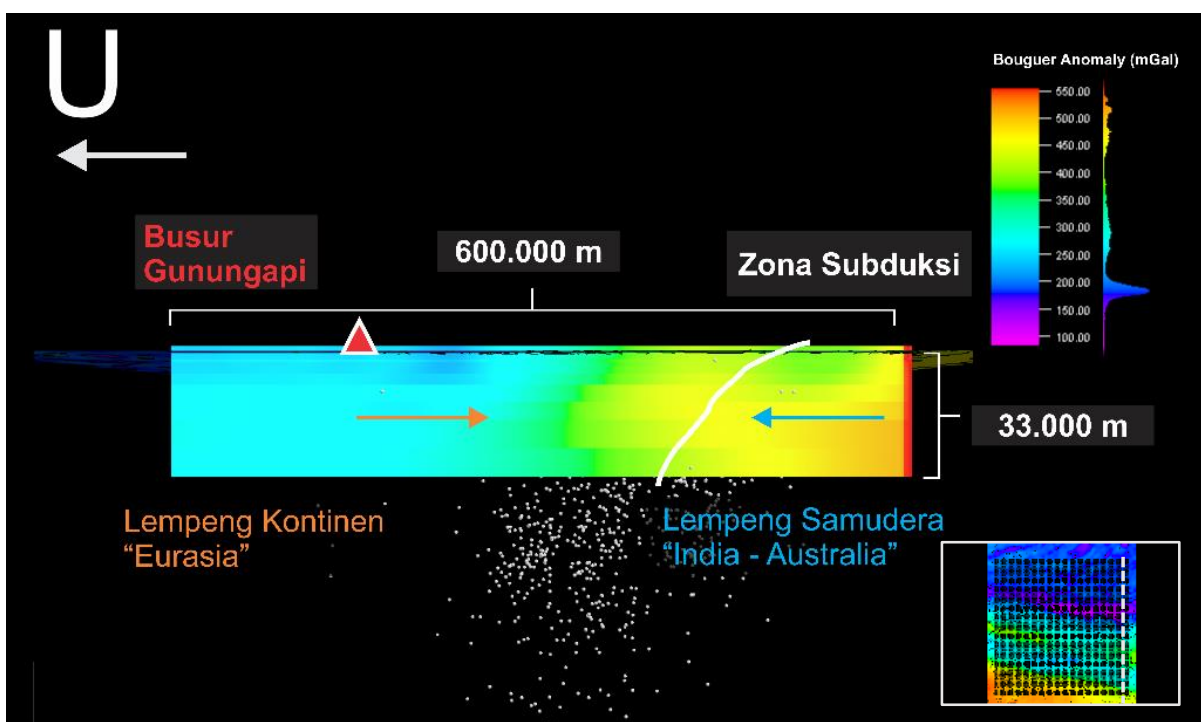

Gambar 12. Penampang Membujur Model 3D Anomali Gravitasi Bawah Permukaan, Tampak dari Barat, Offset $600 \mathrm{~km}$

komponen frekuensi yang dilewatkan pada saat dari lempeng Kontinen Eurasia pada area stres filtering.

Hasil pemodelan 2D menunjukkan bahwa filter mampu memberikan luaran yang diinginkan. Sehingga, selanjutnya dilakukan pemodelan 3D dari rendah, sehingga nilai densitas akibat deformasi juga relatif lebih rendah. Kemudian pada. Anomali gravitasi tinggi merupakan respon dari lempeng Kontinen India-Australia dengan area stres yang 
relatif rendah juga. Pada zona transisi di antara keduanya, terdapat zona subduksi akibat dua lempeng yang konvergen. Yang terjadi pada zona ini adalah adanya stres tinggi yang ditunjukkan oleh nilai anomali gravitasi yang juga relatif lebih tinggi dari pada area stres rendah. Stres tinggi ini menyebabkan pemampatan bodi massa. Ditunjukkan juga pola zona subduksi oleh zona anomali gravitasi rendah yang menurun ke arah Utara pada zona transisi. Pola yang ditunjukkan oleh model anomali gravitasi memberi bentuk zona subduksi dengan sangat mirip, dengan kemenerusan zona subduksi berhimpitan dengan pola distribusi titik hiposenter gempa.

Pada Gambar 8, zona berwarna biru relatif lebih tua menunjukkan zona lempeng benua Eurasia dengan stres rendah. Zona berwarna relatif jingga menunjukkan zona lempeng samudera IndiaAustralia dengan densitas yang relatif lebih tinggi. Serta di tengah menunjukkan transisi antara keduanya, dengan adanya area stres tinggi pada jarak 300 km dari arah Utara. Pada Gambar 9, juga menunjukkan hal yang sama, serta dapat dilihat pola subduksi yang sesuai dengan pola distribusi gempa. Serta area stres tinggi yang lebih lebar pada offset 360 km ini. Pada Gambar 10, juga menunjukkan hal yang sama, dengan area stres yang lebih lebar lagi pada zona transisi.

Dari model tersebut, ditunjukkan bahwa pemodelan telah sesuai dengan geologi tempat penelitian. Nilai anomali gravitasi pada model terdiferensiasi menjadi anomali tinggi, sedang dan rendah. Tinggi-rendahnya nilai anomali disebabkan oleh nilai densitas. Variasi densitas disebabkan oleh pergerakan lempeng yang konvergen, menimbulkan area dengan stres tinggi dan rendah. Geologi daerah pada penelitian ini juga terdiferensiasi oleh kriteria tersebut. Model yang dihasilkan telah menunjukkan kemampuan filter untuk memisahkan Anomali Bouguer menjadi spektrum dari kedalaman di bawah permukaan. Meskipun tidak secara langsung memberikan geometri struktur di bawah permukaan, model Anomali Gravitasi Bouguer hasil Spectral Decomposition ini mampu memberikan petunjuk struktur geologi yang dipengaruhi oleh nilai densitas.

\section{PENUTUP}

\section{Simpulan}

Telah dilakukan desain filter untuk metode Spectral Decomposition pada pemodelan Anomali Gravitasi Bouguer menggunakan Filter 1D lowpass metode Interpolated Finite Impulse Response (IFIR). Filter IFIR telah menunjukkan kemampuan dalam mengisolasi komponen frekuensi rendah dengan akurasi tinggi oleh transition band sempit. Sehingga nilai cutoff frequency yang dipakai sesuai dengan kedalaman teoritis dari spektrum anomali gravitasi terfilter.

Pengaruh Filter 1D lowpass metode IFIR adalah mengatenuasi komponen frekuensi tinggi, memberikan karakteristik regional pada model kedalaman dangkal akibat konten komponen frekuensi yang lebih sedikit. Sehingga, Filter 1D lowpass metode IFIR mampu memberikan petunjuk struktur geologi di bawah permukaan.

\section{Saran}

Penelitian ini dapat ditunjang dengan memanfaatkan metode komputasi yang lebih efisien untuk proses filtering. Selain itu Aplikasi filter pada daerah penelitian dengan struktur geologi yang berbeda. Peneliti juga dapat menentukan parameter statistik untuk melakukan pemodelan. Serta dapat dilakukan pengisian nilai densitas untuk tahap pemodelan seperti pemodelan inversi gravitasi.

\section{DAFTAR PUSTAKA}

Ashadi, A., Harmoko, U., Yuliyanto, G. dan Kaka, S. (2015), "Probabilistic Seismic-Hazard Analysis for Central Java Province, Indonesia", Bulletin of the Seismological Society of America, Vol.105. http://doi.org/10.1785/0120140277.

Biswas, A. (2015), "Interpretation of residual gravity anomaly caused by simple shaped bodies using very fast simulated annealing global optimization", Geoscience Frontiers, Vol.6, No.6, hal.

875-893. http://doi.org/10.1016/j.gsf.2015.03.001.

Blakely, R.J. (1996), Potential Theory in Gravity and Magnetic Applications, Cambridge University Press. 
Geosoft Incorporated (2001), Applying Filters with Montaj Geophysics, hal. 13.

Handyarso, A. dan Kadir, W.G.A. (2017), "Gravity Data Decomposition Based on Spectral Analysis and Halo Wavelet Transform, Case Study at Bird's Head Peninsula, West Papua", Journal of Engineering and Technological Sciences, Vol.49, No.4, hal. 423-437-437. http://doi.org/10.5614/j.eng.technol.sci.2017.4 9.4.1.

Hinze, W.J., Frese, R.R.B. von dan Saad, A.H. (2013), Gravity and Magnetic Exploration by William J. Hinze.

http://doi.org/10.1017/СВ09780511843129.

Jagadale, B.N. (2012), Interpolated Finite Impulse Response (IFIR) Filter Approach: A Case Study,.

Likkason, O. (2011), Spectral Analysis of Geophysical Data, http://doi.org/10.5772/28070.

Lizhe, T.P.D.E.E.U. of N.M. dan Jean, J.P.D.E.E.U. of N.M. (2018), Digital Signal Processing: Fundamentals and Applications, 3 edition., Academic Press, Cambridge, CA.

Lyons, R. (2003), "Interpolated narrowband lowpass FIR filters", IEEE Signal Processing Magazine, Vol.20, No.1, hal. 50-57. http://doi.org/10.1109/MSP.2003.1166628.

Makandar, A. dan Halalli, B. (2015), "Image Enhancement Techniques using Highpass and Lowpass Filters", International Journal of Computer Applications, Vol.109, hal. 21-27. http://doi.org/10.5120/19256-0999.

Mandal, A. dan Niyogi, S. (2018), "Filter assisted bidimensional empirical mode decomposition: a hybrid approach for regional-residual separation of gravity anomaly", Journal of Applied Geophysics, Vol.159, hal. 218-227. http://doi.org/10.1016/j.jappgeo.2018.09.003.

Neuvo, Y., Dong Cheng-Yu dan Mitra, S. (1984), "Interpolated finite impulse response filters", IEEE Transactions on Acoustics, Speech, and Signal Processing, Vol.32, No.3, hal. 563-570. http://doi.org/10.1109/TASSP.1984.1164348.

Pradana, F.H. (2017), Aplikasi Metode Spectral Decomposition pada Data Gaya Berat: Studi
Kasus Pemodelan Zona Subduksi Bagian Timur Pulau Jawa, Undergraduate, Institut Teknologi Sepuluh Nopember. Diambil dari http://repository.its.ac.id/42224/.

Reynolds, J.M. (2011), An Introduction to Applied and Environmental Geophysics, 2nd edition., Wiley, Chichester, West Sussex ; Malden, Mass.

Sandwell, D. dan Smith, W. (2014), "Slope correction for ocean radar altimetry", Journal of Geodesy, Vol.88, No.8, hal. 765-771. http://doi.org/10.1007/s00190-014-0720-1.

Sandwell, D.T., Müller, R.D., Smith, W.H.F., Garcia, E. dan Francis, R. (2014), "New Global Marine Gravity Model from CryoSat-2 and Jason-1 Reveals Buried Tectonic Structure", Science, Vol.346, No.6205, hal. 65-67. http://doi.org/10.1126/science.1258213.

Saramaki, T., Neuvo, T. dan Mitra, S.K. (1988), "Design of computationally efficient interpolated FIR filters", IEEE Transactions on Circuits and Systems, Vol.35, No.1, hal. 70-88. http://doi.org/10.1109/31.1701.

Setiawan, M.R. dan Setiawan, A. (2017), "Pemodelan Struktur Bawah Permukaan Zona Subduksi dan Busur Gunungapi Jawa Timur berdasarkan Analisis Data Gravitasi", Jurnal Fisika Indonesia, Vol.19, No.57. http://doi.org/10.22146/jfi.27092.

Sheriff, R.E. (2002), Encyclopedic Dictionary of Applied Geophysics, Fourth edition, Geophysical References Series, Society of Exploration Geophysicists. http://doi.org/10.1190/1.9781560802969. 